IQTISHADIA Vol. 9, No. 2, 2016, 398-420

P-ISSN: 1979-0724, E-ISSN: 2502-3993

DOI: http://dx.doi.org/10.21043/iqtishadia.v9i2

\title{
Penyelesaian Pembiayaan Murabahah Bermasalah Di Baitul Maal Wa Tamwil (BMT)
}

\author{
Shobirin \\ Prodi Ekonomi Syariah, STAIN Kudus \\ Shobir102@gmail.com
}

\begin{abstract}
Abstrak
Pembatasan wilayah pengkajian dalam artikel ini, bertitik tolak dari tiga landasan keilmuan, yaitu landasan ontologi berkaitan dengan obyek kajian, landasan epistemologi berkaitan dengan metode yang digunakan dalam kajian dan landasan aksiologi berkaitan dengan kegunaan atau signifikasi kajian. Obyek kajian dalam artikel ini adalah penyelesaian pembiayaan murabahah bermasalah di Baitul Maal Wa Tamwil (BMT), terfokus pada dua permasalahan, yaitu faktor-faktor yang menyebabkan adanya pembiayaan murabahah bermasalah diBMT dan mekanisme penyelesaian pembiayaan murabahah bermasalah di BMT. Metode pendekatan yang digunakan untuk pisau analisis, ada dua yaitu: 1) dalam pembiayaan bermasalah diukur dengan teori NPF (Non erforming), dengan pendekatan mencari penyebab terjadinya pembiayaan bermasalah, dan 2) dalam penyelesaian pembiayaan bermasalah menggunakan teori Restrukturisasi pembiayaan, dengan langkah pendekatan sebagai berikut; a) Reschedulling (penjadwalan kembali), b) Reconditioning (persyaratan kembali), c) Restructuring (penataan kembali). Sedangkan signifikasi dalam kajian ini adalah untuk menemukan faktor-faktor penyebab adanya pembiayaan murabahah bermasalah di BMT dan mekanisme penyelesaian pembiayaan murabahah bermasalah di BMT.
\end{abstract}

Kata Kunci: Penyelesaian, pembiayaan murabahah

\section{Abstract}

Restrictions of the study area in this article, based on the three knowledge foundation, the foundation of ontology related to the object of study, the foundation of epistemological with regard to 
the method used in the study and the foundation axiology with regard to the purpose or significance of the study. The object of study in this article is the solving the problem of murabaha financing in Baitul Maal Wa Tamwil (BMT). The study focused on two issues, namely the factors that caused the problem in the murabaha financing and murabaha financing mechanisms to resolve problems in BMT. The study used two analysis model, namely: 1) the financing problems measured by the theory of NPF (Non performing), with the approach of looking for the causes of financing problems, and 2) the completion of the financing problems using theory Restructuring of financing, the approach which is used to restructuring are; a) rescheduling, $b$ ) Reconditioning, c) Restructuring. While the significance of this study is to find the factors that cause the problem in the BMT murabaha financing and murabaha financing mechanisms to resolve problems in $B M T$.

Keywords: Settlement, murabahah financing

\section{PENDAHULUAN}

Institusi keuangan belum dikenal secara jelas dalam sejarah Islam. Namun prinsip-prinsip pertukaran dan pinjammeminjam sudah terjadi pada zaman Nabi Muhammad SAW bahkan sebelumnya. Kemajuan pembangunan ekonomi dan perdagangan telah mempengaruhi lahirnya institusi yang berperan dalam lalu lintas keuangan. Para pedagang dan pengusaha sudah tidak mungkin lagi mengurusi keuangan sendiri (Ridwan, 2005).

Konsep organisasi atau lembaga keuangan sesungguhnya sudah dikenal sejak sebelum Nabi Muhammad diangkat menjadi Rasul. Lembaga baitul maal (rumah dana), merupakan lembaga bisnis dan sosial yang pertama dibangun oleh Nabi Muhammad,lembaga ini berfungsi sebagai tempat penyimpanan (Ridwan, 2005).

Perkembangan perbankan syari'ah pada era reformasi ditandai dengan disetujuinya UU No. 10 Tahun 1998. Dalam Undang-Undang tersebut diatur dengan rinci landasan hukum serta jenis-jenis usaha yang dapat dioperasikan dan 
diimplementasikan oleh bank syari'ah, juga memberikan arahan bagi bank-bank konvensional untuk membuka cabang syari'ah bahkan mengkonversikan diri secara total menjadi bank syari'ah (Syafi'i, 2001).

Perkembangan lembaga-lembaga keuangan syari'ah tergolong cepat, karena keyakinan yang kuat di kalangan masyarakat muslim bahwa perbankan konvensional itu mengandung unsur riba yang dilarang agama Islam. Rekomendasi hasil loka karya tentang bunga bank ditujukan Majelis Ulama Indonesia (MUI) kepada pemerintah dan seluruh umat Islam (Syafi'i, 2001).

Lembaga keuangan telah berperan sangat besar dalam pengembangan dan pertumbuhan masyarakat industri modern. Produksi berskala besar dengan kebutuhan investasi yang membutuhkan modal yang besar tidak mungkin dipenuhi tanpa bantuan lembaga keuangan. Lembaga keuangan merupakan tumpuan bagi para pengusaha untuk mendapatkan tambahan modalnya melalui mekanisme kredit dan menjadi tumpuan investasi melalui mekanisme saving. Lembaga keuangan telah memainkan peranan yang sangat besar dalam mendistribusikan sumber-sumber daya ekonomi di kalangan masyarakat, meskipun tidak sepenuhnya dapat mewakili kepentingan masyarakat luas.

Lembaga keuangan syariah sebagai lembga keuangan alternatif, sebuah lembaga yang tidak saja berorientasibisnis tetapi juga sosial, juga melakukan pemusatankekayaan pada sebagian kecil orang pemilik modal (pendiri) dengan penghisapan pada mayoritas orang, lembaga yang kekayaannya terdistribusi secara merata dan adil. Lembaga yang terlahir dari kesadaran umat dan ditakdirkan untuk menolong kelompok mayoritas yakni pengusaha kecil atau mikro, salah satunya yaitu, Baitul Maal wa Tamwil (BMT) (Ridwan, 2005).

BMT pada dasarnya merupakan pengembangan dari konsep ekonomi dalam Islam terutama dalam bidang keuangan yang kegiatannya mengelola dana yang bersifat nirlaba (sosial) dan menghimpun, menyalurkan dana masyarakat dan bersifat profit motive. Penghimpunan dana diperoleh melalui simpanan pihak ketiga dan penyalurannya dilakukan dalam bentuk pembiayaan atau investasi yang dijalankan berdasarkan prinsip syariah (Muhammad, 2004). 
Penyaluran dana pada BMT dengan prinsip jual beli salah satunya adalah pembiayaan murabahah. Anggota atau nasabah memberikan keuntungan berupa margin yang telah disepakati. Menurut Standar Operasional Prosedur Koperasi Jasa Keuangan Syariah dan Unit Jasa Keuangan Syariah. Pembiayaan merupakan kegiatan penyediaan dana untuk investasi atau kerjasama permodalan antara koperasi dengan anggota, calon anggota, koperasi lain dan atau anggotanya yang mewajibkan penerima pembiayaan itu untuk melunasi pokok pembiayaan yang diterima kepada pihak koperasi sesuai akad disertai dengan pembayaran sejumlah bagi hasil dari pendapatan atau laba dari kegiatan yang dibiayai atau penggunaan dana pembiayaan tersebut (Karim, 2003). Sedangkan Murabahah adalah salah satu akad jual beli barang dengan menyatakan harga perolehan dan keuntungan (margin) yang disepakati oleh penjual dan pembeli. Akad ini merupakan salah satu bentuk natural certainty contracts, karena dalam murabahah ditentukan berapa required rate of profitnya (keuntungan yang ingin diperoleh).

Anggota pembiayaan dalam pelaksanaan pembayaran angsuran pembiayaan sangat variatif, ada yang tepat waktu, ada juga yang lebih awal dari waktu yang telah ditentukan bahkan ada yang tidak tepat waktu pembayaran pembiayaannya, akan tetapi terdapat mitra yang membayar angsurannya tidak sesuai dengan waktu yang telah disepakati sehingga bisa dikatakan bahwa anggota tersebut bermasalah. Sehubungan dengan adanya anggota yang bermasalah tersebut maka akan mempengaruhi pada waktu dan biaya yang dikeluarkan oleh pihak BMT.

Antara pihak BMT dengan anggota, sebelum melakukan transaksi pembiayaan selalu membuat kesepakatan yang disetujui oleh kedua belah pihak, dan kesepakatan tersebut tertuang dalam sebuah akad pembiayaan, baik untuk pembiayaan murabahah, musyarakah dan mudharabah.Dengan demikian secara otomatis keduanya telah terikat oleh perjanjian dan hukum yang telah dibuat bersama. Akan tetapi dalam prakteknya, kadang dijumpai cidera janji atau melanggar janji yang dilakukan oleh pihak anggota tidak melaksanakan kewajibannya terhadap BMT sesuai perjanjian yang telah disepakati sebelumnya, entah karena keadaan memaksa secara sengaja ataupun tidak sengaja. Untuk dapat bertahan ditengah- 
tengah persaingan lembaga keuangan syariah khususnya BMT, perlu adanya upaya-upaya yang harus dilakukan BMT dalam mengatasi pembiayaan bermasalah. Upaya tersebut bisa dilakukan dengan tindakan penyelesaian terhadap anggotanya apabila melakukan ingkar janji atas perjanjian yang telah disepakati.

Seiring dengan perkembangan zaman BMT sekarang menjadi lembaga keuangan yang sangat dibutuhkan oleh masyarakat luas untuk membantu dalam hal permodalan. Penduduk Indonesia sebagian besar merupakan golongan ekonomi menengah ke bawah, eksistensi lembaga keuangan yang bias menyentuh lapisan inilah yang perlu dikembangkan agar kualitas kehidupan masyarakat mengalami perkembangan. BMTpada dasarnya merupakan pengembangan dari konsep ekonomi Islam, terutama dalam bidang keuangan.

BMT merupakan lembaga keuangan yangmenghimpun dana dari masyarakat dan menyalurkan dana tersebut kepada masyarakat yang membutuhkan dana. Hal utama yang membedakannya dengan bank konvensional adalah dalam cara menghimpun dan menyalurkan dana dari masyarakat harus sesuai dengan prinsip-prinsip syari'ah.

Peranan BMT adalah sebagai wadah menghimpun dan menyalurkan dananya pada usaha-usaha yang dilakukan masyarakat dengan berdasarkan pada sistem perekonomian syari'at Islam. Untuk menjalankan peranannya tersebut, maka terdapat produk-produk pendanaan yang beruapa simpanan dan produk-produk penyaluran dana berupa pembiayaan.

Penyaluran dana berupa pembiayaan yang sesuai dengan syariat Islam yang disesuaikan dengan kebutuhan mitra sepertipembiayaan murabahah. Pemberian pembiayaan dapat mendorong peningkatan ekonomi dan kesejahteraan sosial masyarakat dan harus dikelola dengan baik oleh lembaga keuangan tersebut. Sebaliknya pengelolaan pembiayaan yang tidak baik akan banyak menimbulkan masalah bahkan akan menyebabkan ambruknya lembaga keuangan tersebut.

Resiko kredit didefinisikan sebagai resiko kerugian sehubungan dengan pihak peminjam (counterparty) tidak dapat atau tidak mau memenuhi kewajiban untuk membayar kembali dana yang dipinjamnya secara penuh pada saat jatuh tempo atau sesudahnya. Pinjaman yang dimaksud dalam pembahasan resiko 
kredit ini adalah aktiva produktif yaitu alokasi dana bank yang ditempatkan pada pihak lawan trasaksi atau peminjam, dimana peminjam berkewajiban untuk mengembalikan kembali pada waktu yang disepakati. Pengembalian dana dari pinjaman adalah berupa pokok pinjaman ditambah margin atau bentuk investasi lain.

\section{KAJIAN LITERATUR}

\section{Pembiayaan Murabahah}

Dalam SOP KJKS dan UJKS, pembiayaan diartikan suatu kegiatan penyediaan dana untuk investasi atau kerjasama permodalan antara koperasi dengan anggota, calon anggota, koperasi lain dan atau anggotanya yang mewajibkan penerima pembiayaan itu untuk melunasi pokok pembiayaan yang diterima kepada pihak koperasi sesuai akad disertai dengan pembayaran sejumlah bagi hasil dari pendapatan atau laba dari kegiatan yang dibiayai atau penggunaan dana pembiayaan tersebut.

Sedangkan pengertian murabahah menurut para ahli, yaitu suatu akad jual beli barang dengan menyatakan harga perolehan dan keuntungan (margin) yang disepakati oleh penjual dan pembeli. Akad ini merupakan salah satu bentuk natural certainty contracts, karena dalam murabahah ditentukan berapa required rate of profitnya (keuntungan yang ingin diperoleh) (Karim, 2005). Dengan demikian, murabahah merupakan salah satu konsep Islam dalam melakukan perjanjian jual beli.Konsep ini telah banyak digunakan oleh bank-bank dan lembagalembaga keuangan Islam untuk pembiayaan modal kerja, dan pembiayaan perdagangan para nasabahanggotanya (Muhammad, 2000).

Ada yang berpendapat lain, murabahah adalah jual beli dimana harga dan keuntungan disepakati antara penjual dan pembeli. Aplikasi dalam lembaga keuangan, pada sisi aset, murabahah dilakukan antara nasabah/anggota sebagai pembeli dan bank atau BMT sebagai penjual, dengan harga keuntungan disepakati diawal.Pada sisi liabilitas, murabahah diterapkan untuk deposito, yang dananya dikhususkan untuk pembiayaan murabahah saja (Arifin, 1999). Dalam murabahah, penjual menyebutkan harga pembelian barang kepada pembeli, 
kemudian ia mensyaratkan atas laba dalam jumlah tertentu. Pada perjanjian murabahah, bank membiayai pembelian barang yang dibutuhkan oleh nasabah/anggotanya dengan membeli barang itu dari pemasok, dan kemudian menjualnya kepada nasabah/anggota dengan harga yang ditambah keuntungan atau dimark up. Dengan kata lain, penjualan barang kepada nasabah/anggota dilakukan atas dasar cost plus profit (Sudarsono, 2003).

Sedangkan teknis pelaksanannya pembiayaan murabahah dalam BMT sebagai berikut:

a. BMT memberikan pembiayaan dalam bentuk barang dengan membeli secara tunai kepada supplier kemudian menjualnya barang tersebut dengan pembayaran secara angsuaran atau tempo.

b. Selanjutnya BMT menjual barang tersebut kepada anggotanya dengan harga yang telah disepakati bersama dengan menambah margin keuntungan dengan kesepakatan harga yang disepakati bersama.

c. Anggota membayar harga barang dengan cara angsuaran yang telah disepakati jangka waktunya. Dari angsuran kemudian anggota memungkinkan melakukan pola pembayaran secara bertahap sesuai jangka waktu yang telah disepakati bersama (Muhammad, 2000).

Landasan hukumum pembiayaan murabahah, Fatwa MUI Nomor 04/DSN-MUI/IV/2000 tanggal 1 April 2000 tentang murabahah:

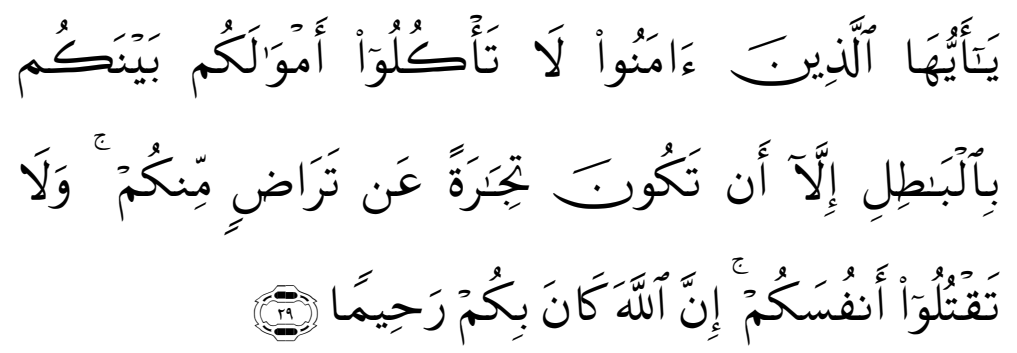

"Hai orang-orang yang beriman, janganlah kamu saling memakan harta sesamamu dengan jalan yang batil, kecuali dengan jalan perniagaan yang berlaku dengan suka sama-suka di antara kamu.dan janganlah kamu 
membunuh dirimu; Sesungguhnya Allah adalah Maha Penyayang kepadamu" (QS. an-Nisa/4:29).

Hadis Rasulullah yang dapat dijadikan rujukan sebagai dasar akad murabahah adalah hadis yang diriwayatkan dari Rafaah bin Rafie R.A. bahwa Rasulullah SAW. Pernah ditanya pekerjaan apakah yang paling mulia, Rasulullah SAWmenjawab: Pekerjaan seseorang dengan tangannya dan setiap jual beli yang mabrur" (HR. Albazzar, Imam Hakim mengkategorikan hadis tersebut, sahih). Dan hadis riwayat dari Abu Said Al-Hudriyyi bahwa Rasulullah bersabda: Seungguhnya jual beli itu harus dilakukan secara suka sama suka (HR. Al Baihaqi, Ibnu Majjah dan Sahih menurut Ibnu Hibban).

Umat Islam juga telah berkonsensus tentang keabsahan jual beli, karena manusia sebagai anggota masyarakat selalu membutuhkan apa yang dihasilkan dan dimiliki oleh orang lain. Oleh karena itu jual beli adalah salah satu jalan untuk mendapatkan harta secara sah (Muhammad, 2004).

Murabahah salah satu jenis jual beli, maka syarat rukunnya samadengan syarat rukun jual beli pada umumnya, menurut jumhur ulama' yaitu: 1) Penjual, 2) Pembeli, 3) Adanya obyek jual beli, 4) Ijab Qabul dan 5) Harga yang disepakati. Jika kelima hal tersebut dipenuhi, maka jual beli dianggap memenuhi rukunnya (Afandi, 2009).

Sedangkan syarat-syarat murabahah adalah sebagai berikut: 1) Harga awal harus dimengerti oleh kedua belah pihak (penjual dan pembeli). Dalam akad murabahah, penjual wajib menyampaikan secara transparan harga beli pertama dari barang yang akan dijual kepada pembeli. Sedangkan pembeli mempunyai hak untuk mengetahui harga beli barang. Persyaratan ini juga berlaku bagi jual beli yang sejenis, seperti: al-isyrak, at-tauliyah, al-wadi'ah. 2) Besarnya keuntungan harus diketahui dan disepakati oleh kedua belah pihak, penjual wajib menyampaikan keuntungan yang diinginkan dan pembeli mempunyai hak untuk mengetahui bahkan menyepakati keuntungan yang akan diperoleh oleh penjual. Jika salah satu dari kedua belah pihak tidak sepakat terhadap keuntungan penjual maka akad murabahah tidak terjadi. 3) Harga pokok dapat diketahui secara pasti satuannya. Seperti satu dirham, satu 
dinar, seratus ribu rupiah, satu kilogram gandum, satu kwintal beras dan lain-lain.Sebab dalam murabahah, dan juga dalam jual beli amanah lainnya, yang dikehendaki adalah adanya transparansi antara harga pokok dan kemungkinan laba yang diperoleh. Jika barang yang akan ditransaksikan tidak diketahui satuannya, maka akan sulit menentukan keuntungan yang akan diperoleh sehingga murabahahpun tidak terjadi. 4) Murabahah tidak bisa dicampur dengan transaksi Ribawi. Pada jual beli barter misalnya, sebuah barang yang dibeli dengan timbangan atau takaran tertentu kemudian dibeli oleh orang lain dengan jenis barang yang sama dengan pembelian pertama, tetapi dengan takaran yang lebih banyak, maka hal demikian disebut sebagai riba. Dalam transaksi murabahah kelebihan bukan disebut sebagai keuntungan, tetapi tetap dikatakan sebagai riba. Lain halnya jika barang tersebut dibeli dengan mata uang kemudian dijual lagi dengan tambahan keuntungan. Atau dibeli dengan barang dengan jenis tertentu, kemudian dibeli lagi oleh orang lain dengan barang yang tidak sejenis. Maka ia tidak disebut sebagai riba. 5) Akad pertama dalam murabahah harus sahih. Jika pada pembelian pertama tidak dilakukan dengan cara yang sahih, maka transaksi murabahah dianggap bata (Afandi, 2009).

Senada dengan beberapa persyaratan di atas, Syafi'i Antonio menetapkan persyaratan murabahah sebagai berikut: 1) Penjual memberi tahu biaya modal kepada nasabah/anggota, 2) Kontrak pertama harus sah sesuai dengan rukun yang ditetapkan, 3) Kontrak harus bebas riba, 4) Penjual harus menjelaskan kepada pembeli bila terjadi cacat atas barang sesudah pembelian, 5) Penjual harus menyampaikan semua hal yang berkaitan dengan pembelian, misalnya jika pembelian dilakukan secara hutang. Secara prinsip, jika syarat dalam (1), (4) atau (5) tidak dipenuhi, pembeli memiliki pilian, bisa; 1) Melanjutkan pembelian seperti apa adanya, 2) Kembali kepada penjual dan menyatakan ketidaksetujuan atas barang yang dijual, dan atau 3) Membatalkan kontrak

Sistem lembaga keuangan murabahah adalah berfungsi sebagai penjual barang untuk kepentingan nasabah atau anggota, dengan cara membeli barang yang diperlukan nasabah atau anggota dan kemudian menjualnya kembali kepada nasabah atau anggota dengan harga jual yang setara dengan harga beli 
ditambah keuntungan dan lembaga keuangan harus memberitahukan secara jujur harga pokok barang berikut biaya yang diperluan dan menyampaikan semua hal yang berkaitan dengan pembelian barang kepada nasabah atau anggota. Namun demikian, sebagai Penyedia barang dalam prakteknya lembaga keuangan syariah (BMT) kerap kali tidak mau dipusingkan dengan langkah-langkah pembelian barang,maka lembaga keuangan syariah (BMT) menggunakan media akad Wakalah dengan memberikan kuasa kepada nasabah atau anggotanya untuk membeli barang tersebut.

Dalam pembiyaan murabahah, terdapat manfaat yang tidak saja semata diperoleh oleh pihak lembaga saja, tetapi juga dapat dirasakan oleh nasabah atau anggota seperti yang disebutkan berikut ini, yaitu: bagi Bank atau BMT: 1) Adanya keuntungan yang muncul dari selisih harga beli, dari penjual dengan harga jual kepada nasabah/anggota, 2) Sumber pendanaan bagi bank baik dalam bentuk rupiah atau valuta asing. Bagi nasabah anggota anggota: 1) Membiayai kebutuhan nasabah/anggota dalam hal pengadaan barang konsumsi seperti rumah, kendaraan atau barang produktif seperti mesin produksi, pabrik dan lain-lain, 2) Nasabah/anggota dapat mengangsur pembayarannya dengan jumlah angsuran yang tidak akan berubah selama masa perjanjian, 3) Dapat diterapkan pada produk pembiayaan untuk pembelian barang-barang investasi baik domestik maupun luar negeri.

\section{HASIL DAN PEMBAHASAN}

\section{Faktor-Faktor Penyebab Adanya Pembiayaan Murabahah Bermasalah di BMT}

Setiap bisnis sudah pasti akan berhadpan dengan berbagai resiko sehingga tidak ada suatu bisnis yang tidak ada resiko. Pemberian pembiayaan sudah pasti mengandun resiko, dan disinilah peran Account Officer untukmemperkecil atau bahkan menghindarkan resiko dengan berbagai rambu yang dipersiapkan sebelumnya (Rivai, 2008).

Di dalam lembaga keuangan syariah (BMT) pada umumnya ada kendala pada pembiayaan dan mengalami masalah, pada pembiayaan murabahah bermasalah yaitu suatu 
keadaan dimana anggota sudah tidak sanggup membayar sebagian atau seluruh kewajiban kepada BMT seperti yang telah disepakati atau diperjanjikan dalam perjanjian pembiayaan.

Berdasarkan hasil observasi di lapangan faktor-faktor yang menyebabkan pembiayaan murabahah bermasalah di BMT pada umumnya adalah dari anggota itu sendiri seperti anggota pindah rumah dan tidak memberi tahukan kepada pihak BMT, anggota mengalami kebangkrutan dalam menjalankan usahanya.Dampaknyadapat mengurangi keuntungan BMT, perputaran uang tidak lancar dan target yang diinginkan BMT tidak tercapai. Faktor-faktor yang menyebabkan pembiayaan murabahahbermasaah di BMT pada umumnya sebagai berikut : a. Faktor intern BMT; 1) kurang pengecekan diawal proses, 2) kurang tajam analisa, 3) kurang paham terhadap kebutuhan keuangannasabah yg sebenarnya, 4) kurang lengkap pencantuman persyaratan, 5) terlalu agresif, 6) petugas yang kurang pengalaman, 7) kurang mengadakan review, 8) adanya kepentingan pribadi dari pengurus, 9) pengikatan jaminan kurang sempurna dan faktor nasabah; 1) tidak kompeten, 2) kurang pengalaman, 3) tidak jujur, dan 4) serakah. b. Faktor eksternal; 1) situasi politik, 2) legal, 3) deregulasi sektor riil, 4) financial, 5) ekonomi dan 6) bencana alam.

Berkaitan dengan permasalahan tersebut, fakta yang ditemukan dilapanganpembiayaan murabahan di BMT pada umumnya dapat dikatagorikan sebagai berikut: 1) lancar menunggak 1 sampai 2 bulan, 2) kurang lancar menunggak 3 sampai 6 bulan, 3) diragukan Mmnunggak 6 sampai 10 bulan, 4) macet menunggak 10 bulan keatas.

Berdasarkan data di lapangan tersebut, dapat dianalisis (a) ada kesalahan dalam mengadakan survey di lapangan oleh pihak BMT, (b) kurang dalam mengetahui karakter nasabah, (c) kurang informasi tentang keadaan nasabah, (d) kualitas itikad baik dari nasabah, (e) kepercayaan pada nasabah tidak selamanya berlaku dengan baik, karena sering kali disalahgunakan, (f) perubahan karakter nasabah, nasabah yang awalnya bagus dalam memenuhi kewajibannya tapi dalam perjalanan pembayaran angsuran berubah jadi tidak lancar karena nasabah lebih mementingkan kebutuhan yang lain, (c) kegagalan usaha nasabah, biasanya disebabkan karena ketidakmampuan nasabah dalam mengelola usahanya. Hal ini 
dapat dilihat dari adanya tidak efektifnya kontrol dan biaya pengeluaran, serta utang yang sulit ditagih. Faktor-faktor diatas menyebabkan usaha nasabah menurun atau bahkan mengalami bangkrut.

Pembiayaan bermasalah adalah pembiayaan yang tidak lancar, di mana debiturnya tidak memenuhi persyaratan yang dijanjikan, pembiayaan yang tidak menepati jadwal angsuran, dan pembiayaan yang memiliki potensi menunggak dalam satuan waktu tertentu. Pembiayaan bermasalah adalah pembiayaan yang kolektabilitasnya tergolong: 1) dalam perhatian khusus (Spesial montion), 2) kurang lancar (Substandar), 3) diragukan (Doubtful), dan 4) macet (loss).

Pembiayaan bermasalah bisa diukur dengan rumus teori NPF (Non erforming), mencaripenyebab terjadinya pembiayaan bermasalah. Munculnya penyebabpembiayaan bermasalah, pada dasarnya tidak terjadi secara tiba-tiba, melainkan melalui suatu proses. Proses tersebut, terjadinya dapat disebabkan baik oleh pihak BMT maupun anggota(Sholihin, 2010).

\section{Mekanisme Penyelesaian Pembiayaan Murabahah Bermasalah di BMT}

Fakta di lapangan hampir semua lembaga keuangan syariah (BMT) pada umumnya, upaya yang dilakukan dalammengurangi pembiayaan bermasalah, yaitu mensyaratkan adanya barang jaminan yang berupa BPKB atau sertifikat tanah. Dengan adanya barang jaminan (agunan) tersebut, jika anggota benar-benar tidak mampu lagi memenuhi kewajibannya maka jaminan tersebut akan dijual.

Langkah-langkah dalam menyelesaikan pembiayaan murabahah bermasalah yang dilakukan adalah menghubungi anggota yang pembayarannya sulit dan menanyakan apa masalahnya dengan melalui pendekatan kekeluargaan dan sifat moral. Tindakan yang dilakukan adalah memberikan peringatan, musyawarah untuk mencapai mufakat, dicari solusi dan tenggang waktu supaya bisa mengangsur, apabila masih tidak bisa membayar maka dilakukan Rescheduling dan Reconditioning pembiayaan atau dilakukan eksekusi jaminan.

Rescheduling dan Reconditioning dilakukan apabila anggota masih ada potensi membayar dan masih ada rasa 
tanggung jawab terhadap pelunasannya. Tetapi jika anggota sudah tidak ada potensi dan tanggung jawab pihak BMT menyarankan untuk penjualan barang jaminan untuk melunasi pembiayaannya. Jika hasil penjualan jaminan masih ada sisa, maka sisa tersebut akan dikembalikan kepada anggota seluruhnya.

Apabila pembiayaan itu masih dapat diharapkan akan berjalan baik kembali, maka daripihak BMT dapat memberikan keringanan-keringanan misalnya menunda jadwal angsuran (rescheduling).

Namun bila kemacetan tersebut akibat kelalaian, pelanggaran atau kecurangan dari nasabah, maka BMT dapat meminta agar nasabah menyelesaikan segera, termasuk menyerahkan barang yang diagunkan kepada BMT. Bila penyelesaian di luar pengadilan tidak dapat dicapai, maka BMTdapat menempuh jalur hukum. Dalam hal ini ada dua cara yang dapat ditempuh, yaitu pengadilan negeri atau badan arbitrase.

Identifikasi permasalahan, sebelum mentukan strategi penyelesaian yang akan dipilih, maka perlu menganalisa dan mengidentifikasi risiko nasabah; 1) kondisi industri atau usahanya, 2) posisi perusahaan dalm industry atau usahanya, 3) kondisi keuangan, 4) keadaan jaminan, dan 5) kualitas manajemen: integritas, kompetensi, aliansi.

Penetapan kondisi pembiayaan, meliputi; 1) besarnya pembiayaan, dalam hal ini kita perlu mengetahui besarnya pembiayaannasabah dan sudah seberapa yang sudah dibayarkan sehinggamengetahui seberapa banyak yang belum dibayarkan, 2) pentingnya masalah ditangani, pembiayaan bermasalah karena ada suatu permasalahan diseorang nasabah, maka dari itu sebelum melakukan tindakan penagihan seorang Remidial (bagian pembiayaan bermasalah) harus mengetahui ada masalah apa yang menyebabkan seorangnasabah tidak lagi mengansur atau menyetor, 3) tindakan penagihan, penagihan pembiayaan bermasalah yang pertama dilakukanadalah mengirim surat tagihan yang di format ringkas danjelas secara 3 atau 4 kali secara berturut-turut, yangdiharapkan nasabah bisa mengerti dan sadar sehingga adakemauan untuk membayar kembali, dan 4) perjanjian kepada nasabah, Melakukan perjanjian kepada nasabah yaitu memberi perjanjian waktu kepada nasabah kapan 
nasabah maumembayar atau mengansur kembali apabila perjanjian itu dilanggar maka pihak BMT Amanah Kudus akan melakukan penyelamatandengan mengeksekusi jaminan.

Tindakan penyelesaian atau penyelamatan, yang dilakukan oleh BMT apabila seorang nasabah masih belum bisa membayar yaitu melelang atau menjual jaminan dari nasabah tersebut, setelah jaminan itu terjual misalkan ada sisa dari penjualan maka sisanya akan dikembalikan kepada nasabah, pihak BMT hanya mengambil sebagian dana yang belum terbayarkan.

BMT pada umumnya dalam melaksanakan akad murabahah selalu memperhatikan ketentuan Fatwa Dewan Syari'ah Nasional MUI, sebagai berikut:

a. Nasabah mengajukan permohonan dan janji pembelian suatu barang atau aset kepada bank.

b. Jika bank menerima permohonan tersebut, ia harus membeliterlebih dahulu aset dipesanya secara sah dengan perdagangan.

c. Bank kemudian menawarkan aset tersebut kepada nasabah dannasabah harus menerima ( membeli) sesuai dengan janji yangtelah disepakatinya, karena secara hukum janji tersebut mengikat,kemudian kedua belah pihak harus membuat kontrak jual beli.

d. Dalam jual beli ini bank dibolehkan meminta nasabah untukmembayar uang muka saat menandatangani kesepakatan awalpemesanan.

e. Jika nasabah kemudian menolak membeli barang tersebut, biayariil bank harus dibayar dari uang muka tersebut.

f. Jika nilai uang muka kurang dari kerugian yang harus ditanggungoleh bank, bank dapat meminta kembali sisa kerugiannya kepadanasabah.

g. Jika uang muka memakai kontrak 'urbun sebagai alternatif dariuang muka, maka

a. Jika nasabah memutuskan untuk membeli barang tersebut, iatinggal membayar harga sisa.

b. Jika nasabah batal membeli, uang muka menjadi milik bank maksimal sebasar kerugian yang diangung oleh bank akibatpembatalan tersebut.; dan 
jika uang muka tidak mencukupi,nasabah wajib melunasi kekuranganya.

Program analisis pembiayaan dilakukan oleh lembaga keuangan syariah (BMT) bertujuan untuk meningkatkan kompetensi pegawai atau staf (BMT) dalam mengelola dana dan melakukan analisis pembiayaan serta menggunakan prinsipprinsip sesuai syariah sehingga tujuan perusahaan dapat tercapai.

Pembiayaan adalah aktifitas menyalurkan dana yang terkumpul kepada anggota pengguan dana, memilih jenis usaha yang dibiayai, dan menentukan anggota mana yang dibiayai agar diperoleh usaha yang produktif, menguntungkan dan dikelola olah anggota yang jujur dan bertanggung jawab.

Tujuan analisis pembiayaan adalah sebagai alat untuk memberikanjawaban pengambilan keputusan tentang masalah masalah seperti :

a. Kepada siapa dana dalam bentuk pembiayaan harus diberikan.

b. Untuk maksud apa dana pembiayaan itu diberikan.

c. Apakah calon anggota debitur yang akan menerima dana pembiayaan mampu mengembalikan pokok pembiayaan ditambah bagi hasil.

d. Berapa jumlah uang yang layak diberikan.

e. Apakah dana pembiayaan yang akan diberikan tersebut cukup aman atau berisiko kecil (Sumiyanto,2008).

Analisis pembiayan yang diperlukan oleh lembaga keuangan syariah(BMT)harus memperhatikan konsep $5 \mathrm{C}$ yaitu adalah sebagai berikut :

a. Character adalah penilaian terhadap karakter atau kepribadian seorang nasabah, dengan tujuan untuk memperkirakan kemungkinan bahwa seorang nasabah yang mengajukan pembiayaan dapat memuhi kewajibanya.

b. Capacity adalah penilaian secara subjektif tentang kemampuan nasabah untuk melakukan pembayaran. Kemampuan ini diukur dengan dengan catatan prestasi seorang nasabah masa lalu yang didukung dengan pengamatan di lapangan atas usaha nasabah, cara berusaha dantempat usaha. 
c. Capital adalah penilaian terhadap kemampuan modal yang dimiliki oleh seorang nasabah, yang diukur dengan posisi usahanya secarakeseluruhan.

d. Collateral adalah jaminan milik calon nasabah. Penilaian untuk lebih menyakinkan jika suatu resikosuatu kegagalan pembayaran terjadi, maka jaminan diganti sebagai pengganti kewajibanya. Tetapi collecteral dalam BMT dapat lebih ditekankan pada factor kepercayaan, pendekatan hubungan kepada pengusaha.

e. Condition adalah dalam pembiayaan BMTharus melihat kondisi perokonomian secara umum, khususnya yang terkait dengan jenis usaha seorang nasabah. Hal itu tersebut dilakukan karena keadaan eksternal usaha yang dibiayai.

Penyelesaian pembiayaan bermasalah dengan menggunakan Restrukturisasi pembiayaan, adalah upaya yang dilakukan BMT dalam rangka membantu nasabah atau anggota agar dapat menyelesaikan kewajibannya (Sholihin, 2010) :

1) Reschedulling (penjadwalan kembali): perubahan jadwal pembayaran kewajiban nasabah/anggota atau jangka waktunya. Penjadwalan kembali tagihan murabahah bagi nasabah/anggota yang tidak bisa menyelesaikan/melunasi pembiayaannya sesuai jumlah dan waktu yang disepakati, dengan ketentuan: tidak menambah jumlah tagihan yang tersisa, pembebanan biaya dalam proses penjadwalan kembali adalah biaya riil dan perpanjangan masa pembayaran harus berdasarkan kesepakatan kedua belah pihak (Sholihin, 2010).

2) Reconditioning (persyaratan kembali): perubahan sebagian atau seluruh persyaratan pembiayaan, antara lain perubahan jadwal pembayaran, jumlah angsuran, jangka waktu dan/atau pemberian potongan sepanjang tidak menambah sisa kewajiban nasabah/anggota yang harus dibayarkan kepada bank (Sholihin, 2010).

3) Restructuring (penataan kembali): perubahan persyaratan tidak terbatas pada rescheduling atau reconditioning, antara lain meliputi: penambahan dana fasilitas pembiayaan, konversi akad pembiayaan, 
konversi pembiayaan menjadi surat berharga syariah berjangka waktu menengah, konversi pembiayaan menjadi penyertaan modal sementara pada perusahaan nasabah/anggota (Sholihin, 2010).

Restrukturisasi pembiayaan murabahah bisa dilakukan dengan ketentuan sebagai berikut: (Sholihin, 2010):

1) Pemberian keringanan: potongan dari total kewajiban pembayaran; potongan pelunasan dini atau jatuh tempo, Fatwa DSN-MUI No. 46/DSN-MUI/II/2005 tanggal 17 Februari 2005 tentang potongan tagihan murabahah, sebagai berikut:

a) LKS boleh memberikan potongan dari total kewajiban pembayaran kepada nasabah/anggota dalam transaksi (akad) murabahah yang telah melakukan kewajiban pembayaran cicilannya dengan tepat waktu dan nasabah/anggota yang mengalami penurunan kemampuan pembayaran.

b) Besar potongan sebagaimana dimaksud di atas diserahkan pada kebijakan LKS

c) Pemberian potongan tidak boleh diperjanjikan dalam akad

2) Penjualan obyek transaksi: secara prinsip obyek telah menjadi milik nasabah/anggota; obyek murabahah dijual kepada atau melalui bank; dari hasil penjualan, nasabah/anggota melunasi utangnya kepada bank; yang menjadi kewajiban/utang nasabah/anggota adalah sisa harga jual (pokok dan margin), namun bank dapat memberikan potongan pelunasan, Fatwa DSN-MUI No. 47/DSNMUI/II/2005 tanggal 22 Februari 2005 tentang penyelesaian piutang murabahah bagi nasabah/anggota yang tidak mampu membayar, sebagai berikut: LKS boleh melakukan penyelesaian (settlement) murabahah bagi nasabah/anggota yang tidak bisa menyelesaikan/melunasi pembiayaannya sesuai jumlah dan waktu yang telah disepakati, dengan ketentuan:

a) Obyek murabahah atau jaminan lainnya dijual oleh nasabah/anggota atau melalui LKS dengan harga pasar yang disepakati. 
b) Nasabah/anggota melunasi sisa utangnya kepada LKS dari hasil penjualan.

c) Apabila hasil penjualan melebihi sisa utang maka LKS mengembalikan sisanya kepada nasabah/anggota.

d) Apabila hasil penjualan lebih kecil dari sisa utang maka sisa utang tetap menjadi utang nasabah/anggota.

e) Apabila nasabah/anggota tidak mampu membayar sisa utangnya, maka LKS dapat membebaskannya.

3) Perpanjangan jangka waktu: perpanjangan masa angsuran atau penangguhan pelunasan tidak boleh mengubah harga jual, Fatwa No. 48/DSNMUI/II/2005 tanggal 25 Februari 2005 tentang penjadwalan kembali tagihan murabahah, sebagai berikut: LKS boleh melakukan penjadwalan kembali (Rescheduling) tagihan murabahah bagi nasabah/anggota yang tidak bisa menyelesaikan/melunasi pembiayaannya sesuai jumlah dan waktu yang telah disepakati, dengan ketentuan:

a) Tidak menambah jumlah tagihan yang tersisa

b) Pembebanan biaya dalam proses penjadwalan kembali adalah biaya riil

c) Perpanjangan masa pembayaran harus berdasarkan kesepakatan kedua belah pihak.

4) Konversi akad: perubahan akad dilakukan dengan menghentikan akad murabahah terlebih dahulu dan membuat akad baru, seperti mudharabah/musyarakah/IMBT, Fatwa No. 49/DSNMUI/II/2005 tanggal 25 Februari 2005 tentang konversi akad murabahah, sebagai berikut: LKS boleh melakukan konversi dengan membuat akad (membuat akad baru) bagi nasabah/anggota yang tidak bisa menyelesaikan/melunasi pembiayaan murabahahnya sesuai jumlah dan waktu yang telah disepakati, tetapi dia masih prospektif, dengan ketentuan:

a) Akad murabahah dihentikan dengan cara: 
(1) Obyek murabahah dijual oleh nasabah/anggota kepada LKS dengan harga pasar

(2) Nasabah/anggota melunasi sisa hutangnya kepada LKS dari hasil penjualan

(3) Apabila hasil penjualan melebihi sisa hutang maka kelebihan itu dapat dijadikan uang muka untuk akad ijarah atau bagian modal dari mudharabah dan musyarakah

(4) Apabila hasil penjualan lebih kecil dari sisa hutang maka sisa hutang tetap menjadi hutang nasabah/anggota yang cara pelunasannya disepakati antara LKS dan nasabah/anggota.

a) LKS dan nasabah/anggota ex-murabahah tersebut dapat membuat akad baru dengan akad:

(1) Ijarah Muntahiyah Bit Tamlik atas barang tersebut diatas dengan merujuk kepada fatwa DSN No. 27DSN-MUI/III/2002 tentang AlIjarah Muntahiyah Bi Al-Tamlik

(2) Mudharabah dengan merujuk kepada fatwa DSN No. 07/DSN-MUI/IV/2000 tentang pembiayaan Mudharabah (Qiradh) atau

(3) Musyarakah dengan merujuk kepada fatwa DSN No. 08/DSN-MUI/IV/2000 tentang pembiayaan Musyarakah

\section{PENUTUP}

Berdasarkan pembahasan pada bab sebelumnya, artikel ini dapat disimpulkan sebagai berikut:

1. Faktor-faktor yang mengakibatkan pembiayaan murabahah bermasalah di BMT pada umumnya.

a. Faktor dari dalam: 1) Faktor dari pengelola BMT; kurang hati-hati dalam menganalisa, kurang selektif, manajer terlalu mudah percaya pada marketing dan marketing terlalu mudah percaya pada anggota, dengan kesimpulan: a) kurang pengecekan diawal proses, b) kurang tajam analisa, c) kurang paham terhadap 
kebutuhan keuangan nasabah ygsebenarnya, d) Kurang lengkap pencantuman persyaratan, e) terlalu agresif, f) petugas yang kurang pengalaman, g) kurang mengadakan review, h) adanya kepentingan pribadi dari pengurus, i) pengikatan jaminan kurang sempurna. 2) Faktor dari nasabah; kualitas itikad baik dari nasabah yang kurang, perubahan karakter nasabah dan kegagalan usaha nasabah, adanya unsur kesengajaan atau perubahan karakter nasabah: dalam hal ini anggota sengaja untuk tidak bermaksud membayar kewajibannya kepada BMT atau dapat dikatakan tidak adanya unsur kemauan untuk membayar, walaupun sebenarnya anggota mampu, dalam hal ini anggota memang tidak mempunyai i'tikad baik untuk membayar angsuran, anggota memiliki pembiayaan lain selain di BMT yang memberi pembiayaan, dan mengalami bangkrut dalam usahanya, dengan kesimpulan: a) tidak kompeten, b) kurang pengalaman, c) tidak jujur, dan d) serakah.

b. Faktor dari luar: adanya faktor ketidak sengajaan (faktor alam) berupa informasi dari nasabah atau anggota kurang jelas untuk BMT mengenai : Situasi politik, legal, deregulasi sektor riil, financial, ekonomi dan bencana alam

2. Mekanisme penyelesaian pembiayaan murabahah bermasalah di bmt pada umumnya.

Mekanisme penyelesaian pembiayaan murabahah bermasalah di BMT pada umumnya adalah: a. Dengan cara identifikasi permaslahan yang meliputi melihat kondisi usahanya, posisi industri atau usahanya, kondisi keuangan, kondisi jaminan dan kualitas manajemen, b. Penetapan kondisi pembiayaan yang meliputi besarnya pembiayaan, pentingnya masalah yang ditangani, tindakan penagihan dan perjanjian kepada nasabah, c. Tindakan penyelesaian atau penyelamatan. d. Kemudian melakukan surat peringatan I, II dan III, surat peringatan digunakan secara bertahap, e. Rescheduling dan Reconditioning, digunakan apabila anggota masih ada potensi membayar atau masih ada tanggung jawab untuk membayar, f. Penjualan Jaminan, dilaksanakan apabila anggota benar- 
benar sudah tidak mampu dan sudah tidak ada rasa tanggung jawab untuk melunasi. Tetapi pihak BMT sebisa mungkin penyelesaian pembiayaan tidak sampai pada penjualan jaminan, dan penjualan barang jaminan dilakukan apabila anggota benar-benar sudah tidak bias memenuhi kewajibannya. Dalam penyelesaian pembiayaan bermasalah tidak ada tim khusus untuk menyelesaikan. Jadi manajer dan markrting yang menyelesaikan. Dalam penyelesaian dengan cara kekeluargaan dan musyawarah.

Upaya untuk menunjang kelangsungan usaha suatu perusahaan memerlukan dana yang cukup untuk membiayai seluruh kegiatan operasi dan untuk mencapai tujuan usaha, yaitu memperoleh keuntungan. Dalam operasional usaha bank konvensional memberikan kredit kepada peminjam atau debitur, sedangkan lembaga keuangan syariah (BMT) memberikan pembiayaan kepada nasabah atau anggota yang akan dibiayai. Dalam pembiayaan lembaga keuangan syariah (BMT) sebagai pemilik dana membelikan barang sesuai dengan spesifikasi yang diinginkan oleh anggota yang membutuhkan pembiayaan, kemudian menjualnya kepada anggota tersebut dengan menambah keuntungan tetap. Anggota akan mengembalikan utangnya dikemudian hari secara tunai maupun secara angsuran. Pemberian pembiayaan tanpa dianalisis terlebih dahulu akan sangat membahayakan lembaga keuangan syariah (BMT). Anggota, dalam hal ini akan sangat mudah memberikan datadata fiktif. Walaupun sebenarnya tidak layak, tetapi masalah diberikan kemudian jika salah menganalisis, maka pembiayaan yang disalurkan yang sebenarnya tidak layak menjadi layak sehingga akan berakibat sulit untuk ditagih atau bermasalah. Namun, faktor analisis ini bukanlah merupakan penyebab utama pembiayaan bermasalah.Penyebab lainnya mungkin disebabkan oleh bencana alam yang memang tidak dapat dihindari anggota, misalnya kebanjiran, tanah longsor atau dapat pula kesalahan dalam mengelola usahanya.

Dalam memaksimalkan pengelolaan dana, manajemen BMT harus memperhatikan tiga aspek penting yang berkaitan dengan pembiayaan, yaitu:

a. Aman, yaitu keyakinan bahwa dana yang telah di lempar dapat ditarik menciptakan kondisi tersebut, sebelum 
dilakukan pencairan pembiayaan, BMT terlebih dahulu harus melakukan survey usaha untuk memastikan bahwa yang dibiayai layak. Dilarang memberikan pembiayaan hanya karena faktor kasihan. BMT harus betul-betul jeli dalam melihat usaha yang diajukan, menciptakan kondisi tersebut, sebelum dilakukan pencairan pembiayaan, BMT terlebih dahulu harus melakukan survey usaha untuk memastikan bahwa yang dibiayai layak. Dilarang memberikan pembiayaan hanya karena faktor kasihan. BMT harus betul-betul jeli dalam melihat usaha yang diajukan.

b. Lancar, yaitu keyakinan bahwa dana BMT dapat diputar dengan lancar dan cepat. Semakin cepat putaran dananya, maka pengembangan BMT akan semakin baik. Maka BMT harus membidik sekmen pasar yang putarannya harian atau mingguan. Komposisi antara yang bulanan dan harian atau mingguan harus berimbang dan akan lebih baik jika hariannya lebih banyak.

c. Menguntungkan, yaitu perhitungan yang tepat, untuk memastikan bahwa dana yang dilempar akan menghsilkan pendapatan. Semakin tepat dalam memroyeksi usaha, kemungkinan besar gagal dapat diminimalisasi. Kepastian pendapatan ini memiliki pengaruh yang besar bagi kelangsungan BMT. Karena para deposan akan secara langsung merasakan dampaknya. Semakin besar pendapatan BMT akan semakin besar pula hasil yang diterima oleh anggota penabung dan sebaliknya. 


\section{DAFTAR PUSTAKA}

Antonio, M. Syafi'i. (2001). Bank Syariah: Dari Teori ke Praktik, Gema Insani Press, Jakarta.

Arifin, Zainul. (1999). Memahami bank Syariah - Lingkup, Peluang, Tantangan dan Pospek, Alfabet, Jakarta.

Afandi, Yazid. (2009). Fiqih Muamalah dan Impementasinya dalam Lembaga Keuangan Syariah, Logung Pustaka, Yogyakarta.

Karim, Adiwarman. (2005). Manajemen Baitul Maal wat Tamwil, UII Press, Yogyakarta.

Muhammad. (2000). Sistem dan Prosedur Operasional Bank Syariah, UII Press, Yogyakarta.

(2004). Manajemen Dana Bank Syariah, Remaja Rosda Karya, Bandung.

Ridwan.,M. (2005). Manajemen Baitul Maal wat Tamwil, UII Press, Yogyakarta.

Rivai Veithzal, Veithzal, Andria Permata. (2008). Islamic Financial Management, PT Raja Grafindo Persada, Jakarta.

Sumiyanto, A. (2008). BMT Menuju Koperasi Modern, Ises Publishing, Jakarta.

Sholihin, A. Ifham. (2010). Buku Pintar Ekonomi Syariah, Gramedia Pustaka Utama, Jakarta.

Sugiarto, Ferry N. Idroes. (2006). Manajeman Resiko Perbankan, Graha ilmu, Yogyakarta.

Sudarsono, Heri. (2003). Bank dan Lembaga Keuangan Deskripsi dan Ilustrasi, Ekonisia, Yogyakarta.

Tim Penulis DSN-MUI. (2006). Himpunan Fatwa Dewan Syari'ah Nasional, CV.Gaung Pesada, Jakarta.

http//www.smecda.com_pembiayaan_SOP_KJKS diakses pada tanggal 3 Agustus 2015

http://hendrakholid.net/blog/2009/10/21/pembiayaanmurabahah/ diakses 3 Agustus 2015

http://pandidikan.blogspot.com/2011/06/pembiayaanbermasalah-dan-ruang.html diakses pada tanggal 3 Agustus 2015 